\title{
UNIA EUROPEJSKA I NATO WOBEC WOJNY HYBRYDOWEJ NA UKRAINIE
}

\author{
THE ATTITUDE OF THE EUROPEAN UNION AND NATO \\ TOWARDS THE HYBRID WAR IN UKRAINE
}

Anna Antczak-Barzan*

\begin{abstract}
ABSTRAKT
Artykuł ma na celu ukazanie przyczyn konfliktu na Ukrainie w odniesieniu do struktur zachodnich - Unii Europejskiej oraz NATO i ich reakcji na wydarzenia, jakie miały i mają miejsce w tym kraju, a także oczekiwań społeczności międzynarodowej i samej Ukrainy względem tych graczy. Artykuł uwypukla także specyficzne cechy konfliktu, które wskazują na jego hybrydowy charakter, wyjaśniając jednocześnie przyczyny i możliwe skutki.
\end{abstract}

Słowa kluczowe: NATO, Unia Europejska, Ukraina, wojna, konflikt
The article aims at presenting the reasons of the conflict in Ukraine with respect to the Western structures - the European Union and the North Atlantic Alliance, as well as the reaction of those on the developments in this country with relation to the expectations of the international community and Ukraine itself. It also indicates these characteristics of the war which point out its hybrid nature, together with an explanation of their causes and possible consequences.

Keywords: NATO, European Union, Ukraine, war, conflict

* Akademia Finansów i Biznesu Vistula w Warszawie, Wydział Biznesu i Stosunków Międzynarodowych. 


\section{WSTĘP}

„Po ostatniej fali zbiorowej ekstazy nastał poranek rozczarowań” (Toffler, Toffler, 2006, s. 24) - w ten sposób Alvin i Heidi Toffler komentują powszechne przekonanie, iż żyjemy w epoce pokoju, w świecie, któremu nie grożą wojny światowe, a już na pewno nie wojny z udziałem wielkich mocarstw. Przykład Ukrainy pokazuje, że wojna może się toczyć w Europie, tuż za granicami potężnego NATO i być prowokowana przez wielkie mocarstwo, które ostatecznie po prostu wzięło w niej udział. A zatem dopiero teraz, w obliczu działań, jakie podjęła Rosja na terenie Ukrainy, zaczęto powracać do kwestii wojny, nazywanej hybrydową, nie tylko w aspekcie politycznym czy obronnym, ale także ekonomicznym. Okazało się, że sieć powiązań ekonomicznych nie musi oznaczać braku możliwości prowadzenia wojny, gdyż jej wymiar zupełnie się zmienił. Niniejszy artykuł wskaże niektóre czynniki leżące po stronie Zachodu, które umożliwiły Rosji podjęcie określonych działań na Ukrainie, a także będzie stanowił próbę znalezienia odpowiedzi na pytanie, jaki jest stosunek państw zachodnich do kryzysu tuż za wschodnią granicą Polski.

Pomimo powszechnej opinii, że Europie nie grozi klasyczny konflikt zbrojny, Unia Europejska musi się obecnie zmierzyć z problemem, jaki powstał tuż u jej wschodnich granic. Ukraina stanowi dobitny przykład na to, że teoria „wielkiego pokoju” (zob. też Fettweis, 2010) nie sprawdziła się, natomiast obawy narodów, związanych niegdyś z ZSRR, przed neoimperialnymi dążeniami Rosji nie są nieuzasadnione. UE okazała się wobec nich bezsilna i nie była w stanie skutecznie odgrywać roli gwaranta bezpieczeństwa w regionie. Fakt ten, w połączeniu z zupełnie niewykorzystaną szansą, jaką stanowiła tzw. pomarańczowa rewolucja na Ukrainie z przełomu 2004 i 2005 r., doprowadził Europę do momentu, w którym będzie zmuszona dokonać wyboru - zademonstrować siłę bądź ulec imperium rosyjskiemu, uznając w ten sposób jego potęgę. Żaden wybór nie będzie pozbawiony daleko idących konsekwencji, które także będą musiały zaowocować zmianami, te zaś w mniejszy lub większy sposób dotkną wszystkie państwa członkowskie, a Polskę i państwa Bałtyckie w stopniu najwyższym. 


\section{HYBRYDYZACJA WOJNY}

Na początku warto się zastanowić, jaki rodzaj konfliktu toczy się na Ukrainie. Coraz częściej mówi się, że wojny ponowoczesne przybierają postać hybrydowych, co oznacza, że stare sposoby oraz narzędzia prowadzenia wojny pozostaną nadal w użyciu, lecz coraz częściej towarzyszyć im będą nowe - ponowoczesne. A zatem należy postawić w tym miejscu pytanie, czym jest wojna hybrydowa? Hybrydyzacja wojny, jak pisze Jacek Czaputowicz, wyraża współwystępowanie różnych ich generacji - stron konfliktu (państwa i aktorzy pozapaństwowi, żołnierze i osoby cywilne), a także typów działań zbrojnych - symetryczne i asymetryczne (Czaputowicz, 2012, s. 61-62). Być może właśnie hybrydyzacja wojny stanowi najistotniejszy wyznacznik zmian pomiędzy wojną „klasyczną” a ponowoczesną. Dodatkowo zauważalny jest nowy wymiar wojny informacyjno-propagandowej, a także powrót do użycia sił o charakterze partyzanckim oraz operacji prowadzonych przez niewielkie, ale doskonale wyszkolone grupy żołnierzy służb specjalnych. Innym od wymienionych powodem wojen jest fanatyzm religijno-kulturowy, zaś rekrutacja do armii ma charakter propagandowy i stanowi wyraz indoktrynacji polityczno-kulturowo-religijnej, prowadzonej od narodzin dziecka.

Nowy rodzaj wojny polega przede wszystkim na wykorzystaniu innych środków niż broń konwencjonalna. Dotyczy głównie prowadzenia długofalowej, określonej (odpowiednio ukierunkowanej) polityki opartej na bardzo precyzyjnej strategii, polegającej na budowaniu powiązań międzynarodowych, a także używaniu narzędzi tradycyjnie nieprzeznaczonych do prowadzenia wojny, czyli np. mniejszości narodowych czy propagandy informacyjnej oraz formuły nieokupacyjnej. Chcąc poprzeć teorię faktami, warto odwołać się do bieżących przykładów. Wydarzenia na Ukrainie dobitnie pokazują, do jakiego stopnia można wykorzystać nowe techniki prowadzenia polityki oraz narzędzia wojny informacyjnej. Najbardziej zaskakującym elementem tego konfliktu (w zestawieniu z niemalże średniowiecznymi barykadami i katapultami stosowanymi przez protestujących na kijowskim Majdanie) było użycie telefonów komórkowych oraz prostych aparatów cyfrowych jako tarcz, które miały chronić ich właścicieli poprzez rozprzestrzenianie określonych informacji. Miało to spowodować zainteresowanie społeczności międzynarodowej i jej interwencję, co, jak widać, jednak nie nastąpiło. $Z$ drugiej zaś strony funkcjonowała bardzo dobrze zorganizowana propaganda rosyjska, która przedstawiała w mediach członków tymczasowego rządu w Kijowie i ich zwolenników jako faszystów, 
którzy przywiedli Ukrainę na skraj wojny domowej. Rola rosyjskiej propagandy jest ogromna. Koncentrowała się przede wszystkim na podkreślaniu, że rząd w Kijowie był nielegalny i pozbawiony realnej władzy oraz podejmował bezprawne działania w stosunku do separatystów. Taki przekaz kopiowany był przez znaczną część zachodnich mediów, zaś społeczeństwo rosyjskie jest permanentnie dezinformowane i manipulowane przez rządową propagandę. Celem nadrzędnym jest oczywiście wygranie wojny informacyjnej, a w konsekwencji i całej wojny. Państwa czy też podmioty pozapaństwowe, tocząc wojnę w XXI wieku, zdają sobie doskonale sprawę z tego, że obecnie liczy się przede wszystkim odbiorca, czyli audytorium, oraz to, w jaki sposób zaprezentuje się temu audytorium swoje poczynania. A zatem, dla przykładu, rosyjski sukces w prowadzeniu wojny informacyjnej jasno wskazuje na to, w jakim stopniu takie pojęcia, jak: wojna, okupacja i interwencja, odbiegają obecnie od swych klasycznych definicji i sposobów ich pojmowania.

Przypatrując się rozwojowi sytuacji na Ukrainie, można się zastanowić, czy mamy do czynienia z nowym rodzajem wojny, a jeśli tak, to jakie są jej najważniejsze cechy. „Nowa” wojna nie zawsze musi się wiązać z bezpośrednim użyciem siły militarnej. Często zastosowanie środków niemilitarnych (o charakterze politycznym, ekonomicznym czy społecznym) powoduje osiągnięcie podobnego efektu bez użycia broni i ponoszenia kosztów osobowych (ofiar). Takie środki są często stosowane w konfliktach asymetrycznych, w stosunku do państw słabych czy upadłych (słaby aparat państwowy, niejednolite społeczeństwo, słabe siły zbrojne, rozwarstwienie społeczne, niestabilny system polityczny itp. - wszystkie te elementy zostały wykorzystane przez Rosję na Ukrainie). Odmienny od „tradycyjnego" sposób na podporządkowywanie sobie terytorium przez państwa trzecie bądź ugrupowania pozapaństwowe (grupy narodowościowe, etniczne, czy też tworzone ad hoc grupy interesu) znalazły odzwierciedlenie w działaniach separatystycznych grup stanowiących mniejszości narodowe, etniczne czy religijne, bądź nawet wyznaniowe. Zatem stały się one nową, całkiem potężną „bronią”, a racje prezentowane przez mniejszości - przynajmniej pozornie - są trudne do zakwestionowania (np. przywoływane jest prawo do samostanowienia, mimo że jest ono oczywiście w tym przypadku niewłaściwie pojmowane). Separatyzm umożliwia ukierunkowanie i pewną formę „zmaterializowania” niezadowolenia części społeczeństwa z obecnej sytuacji w taki sposób, że osiągnięcie kompromisu staje się praktycznie niemożliwe, gdyż nie ma żadnych punktów wspólnych, na których można by było zacząć budować porozumienie. Jeśli mniejszość odczuwa lub raczej jest do tego inspirowana, że jej prawa nie są 
szanowane, a w danym społeczeństwie nie znajduje ona dla siebie miejsca i szuka alternatywnych rozwiązań, aby zabezpieczyć swą przyszłość, to staje się bardziej podatna na działania propagandy.

Niezwykle istotną kwestią, na którą warto zwrócić uwagę, jest narzędzie interwencji (humanitarnej). Instrument wykorzystywany jako militarna (i nie tylko) interwencja w wewnętrzny konflikt innego państwa nabiera w XXI wieku zupełnie innego znaczenia niż miało to miejsce wcześniej. Aparat uznany przez prawo międzynarodowe zaczyna być wykorzystywany w zupełnie innych celach niż te, do jakich został stworzony. Pod pretekstem organizowania pomocy humanitarnej czy też zapobiegania rozprzestrzenianiu się przemocy, na teren innego kraju wprowadzane są obce siły zbrojne, które mogą działać niekoniecznie zgodnie $\mathrm{z}$ wolą tego państwa (czerpiąc $\mathrm{z}$ najświeższych wydarzeń, najlepszym przykładem są działania Rosji podejmowane w Gruzji, Abchazji oraz na Ukrainie). Recz w tym, że interwencja humanitarna może być przeprowadzona bez zgody państwa, na którego terytorium mają być wprowadzone obce siły zbrojne, jednak celem jest zapobieżenie łamaniu praw człowieka i ochrona ludności cywilnej - zawsze brały w niej udział siły wielonarodowe, zaangażowane były instytucje międzynarodowe, w tym ONZ. Szczytem cynizmu jest jednak wykorzystywanie pozorów pomocy humanitarnej (transportów) do wspierania i podżegania działań o charakterze konfliktu czy wojny w innym państwie, by w ten sposób bronić własnych interesów narodowych (rosyjski „biały konwój” na Ukrainie, przeznaczony do wykonywania zadań na rzecz państwa wysyłającego w strefie opanowanej przez pro-rosyjskich separatystów).

Kolejnym problemem jest stosowanie przez Rosję politycznego narzędzia, jakim jest wojna „bez okupacji”, typowy fenomen występujący wyłącznie na obszarach postsowieckich, który przepełniony jest cynizmem, szczególnie w odniesieniu do tego, co władze Rosji nazywają „interwencją humanitarną”. W ten sposób Władimir Putin usprawiedliwia swoje działania o charakterze „okupacji bez okupacji”, pozostawiając pytanie o moralny wydźwięk nazywania takich działań interwencją humanitarną bez jakiejkolwiek odpowiedzi czy reakcji ze strony społeczności międzynarodowej. „Pokój” w wydaniu rosyjskim będzie w istocie oznaczał zastraszanie i dominację ukryte pod maską stabilizacji. Paradoks tej sytuacji polega na tym, że stan wojny staje się stanem pokoju, zaś interwencja humanitarna - środkiem zastępczym dla prowadzenia wojny bez formalnego jej wypowiadania.

To, co jest zaskakujące podczas analizy najnowszych działań podejmowanych przez państwa, to otwarte (bo już nawet nie zawoalowane) kłamstwo z jednej 
strony oraz udawanie wiary w dobre intencje przez „odbiorcę” tych komunikatów (taka sytuacja ma miejsce pomiędzy Rosją a Zachodem w kontekście konfliktu [wojny?] na Ukrainie). Władimir Putin przedstawia w mediach i rozmowach z przywódcami innych państw europejskich wizję nieistniejącej rzeczywistości, która to jest przyjmowana za dobrą monetę. Kpina ze społeczeństw, ich przywódców politycznych oraz przede wszystkim z Ukrainy przybiera już postać karykaturalną, jednak nikt na szczeblach rządowych nie chce tego otwarcie przyznać.

Skoro jest przyzwolenie społeczności międzynarodowej na takie postępowanie, prezydent Rosji skrzętnie z niego korzysta, karmiąc wszystkich dookoła medialną papką składającą się z kłamstw, szyderstw i manipulacji.

W przypadku prób aneksji Krymu przez Rosję powoływano się między innymi na zapisane w Karcie Narodów Zjednoczonych prawo do samostanowienia. Jak wiadomo, zapis ten dotyczył przede wszystkim procesów dekolonizacyjnych, a zatem próby powoływania się na to prawo przez mniejszości etniczne zamieszkujące wybrane części terytoriów niepodległych państw, często ościennych, sązupełnie niewłaściwe. Należałoby dokonać rozróżnienia pomiędzy dążeniem do autonomii czy też odrębności państwowej narodowości lub grup etnicznych, które zostały wcielone do innych państw lub połączone, a odrywaniem części terytorium od jednego państwa i przyłączaniem do drugiego pod hasłem prawa do samostanowienia. Taka sytuacja pozwala na wykorzystywanie mniejszości narodowych zamieszkujących terytoria innego państwa do „legalnego" pozbawiania go części jego terytorium. Z pewnością nie powinno to nosić znamion legitymizacji międzynarodowej i uznania wśród tej społeczności.

W 2007 r. Michael Sheehan pisał, że „wśród konfliktów niedotyczących bezpośrednio wielkich mocarstw zaczynają przeważać wojny o chaotycznej strukturze, prowadzone $\mathrm{z}$ użyciem nisko zaawansowanej broni i z funduszy uzyskiwanych na własną rękę przez zaangażowanych w nią drobnych, niepaństwowych aktorów" (Sheehan, 2007, s. 66). Ciekawy na tym tle jest przypadek Rosji, która jest uznawana za mocarstwo, a posługuje się podobnymi metodami, jak opisane wyżej. W konflikcie z Ukrainą Rosja angażuje się w sposób niebezpośredni (przynajmniej na poziomie wydawanych komunikatów adresowanych do społeczności międzynarodowej), czyli na poziomie państwa utrzymywana jest propaganda informacyjna, mająca na celu ukazanie Rosji jako wspaniałomyślnego i wielkodusznego sąsiada, który chce tylko wspierać państwo ościenne pogrążone w chaosie. W rzeczywistości Rosja wspiera prorosyjskich separatystów nie tylko finansowo, ale także militarnie (sprzęt, uzbrojenie, żołnierze) w sposób 
nieoficjalny, co przynosiło przez dłuższy czas efekt wojny chaotycznej z użyciem nisko zaawansowanej broni. A zatem można stwierdzić, że nowym sposobem (czy tylko narzędziem?) prowadzenia wojny staje się „partyzantka” z użyciem służb specjalnych.

Idea responsibility to protect jest natomiast wykorzystywana przez Rosję w równym stopniu co interwencja humanitarna. Pod pretekstem ochrony ludności lokalnej, w tym własnych mniejszości narodowych, Rosja podejmuje działania o różnym charakterze na terenie wschodniej Ukrainy - od szeroko zakrojonych działań politycznych (w tym także ekonomicznych, dotyczących również państw zaangażowanych w konflikt - głównie w odpowiedzi na sankcje Zachodu, które stały się pretekstem do zaostrzenia polityki względem państw, w stosunku do których Rosja zawsze przejawiała daleko idącą niechęć - m.in. Polski) poprzez zakamuflowane działania militarne, na „humanitarnych” skończywszy (konwój kilkuset ciężarówek wysłanych na Ukrainę).

Nowoczesne techniki to też możliwość łatwej manipulacji obrazem czy dźwiękiem i upublicznianie informacji nieprawdziwej, przetworzonej, zmanipulowanej - dla osiągnięcia określonego celu propagandowego. Nierzadko się zdarza, że prezentowany materiał pochodzi z innego miejsca, czasu, sytuacji, natomiast przeciętny odbiorca nie jest w stanie dostrzec manipulacji. Taką strategię często stosuje propaganda rosyjska, w szczególności podczas tworzenia wiadomości z przeznaczeniem dla mediów zachodnich. Wykorzystuje się także motyw brutalności postępowania strony przeciwnej (szczególnie „pożądane” są obrazy ukazujące przemoc stosowaną wobec kobiet oraz dzieci). Ukazywanie cierpienia ludności cywilnej podczas konfliktu zbrojnego, stało się podstawowym orężem stosowanym w wojnie informacyjnej. Tego typu działania można zaobserwować, analizując przekaz płynący z kryzysu na Ukrainie.

\section{REAKCJE UE ${ }^{1}$ I NATO WOBEC KONFLIKTU NA UKRAINIE}

Odmowa parafowania umowy stowarzyszeniowej pomiędzy UE a Ukrainą przez prezydenta Janukowycza podczas szczytu Partnerstwa Wschodniego w listopadzie 2013 r. w Wilnie stała się punktem zwrotnym w historii kraju.

${ }^{1}$ Część dotycząca Unii Europejskiej została napisana na podstawie Antczak-Barzan, A. (2015). Wymuszona adopcja niechcianego dziecka - czyli stosunek Unii Europejskiej do konfliktu na Ukrainie. W: Potocki, R., Domagała, M., Miłoszewska, D. (red.), Czas EuroMajdanu. Imperatywy (de)stabilizacji 
Ostatecznie 21 marca 2014 r. UE i Ukraina podpisały polityczną część umowy stowarzyszeniowej (zob. też EU-Ukraine relations, 2014), która zaczęła obowiązywać 1 listopada 2014 r. Ustalono także, że pozostała część umowy dotycząca kwestii handlowych ma wejść w życie dopiero przed końcem 2015 r. (European Parliament ratifies EU-Ukraine Association Agreement, 2014).

Oczekiwania tymczasowego rządu Ukrainy i znacznej części społeczeństwa wobec Unii Europejskiej oraz NATO od początku konfliktu były znaczne, jeśli nawet nie ogromne. Wynikały one z przekonania, że Zachód nie opuści Ukrainy zmagającej się z „rosyjskim jarzmem” i dążącej do zjednoczenia ze strukturami zachodnimi. Realia okazały się natomiast zupełnie inne. Nie dość, że Unia nie spełniła pokładanych w niej ukraińskich oczekiwań, które budowane były w oparciu o romantyczne idee oraz tzw. wishful thinking, to nie była w stanie nawet określić jakiegokolwiek czytelnego wspólnego stanowiska w sprawie ukraińskiej, nie wspominając nawet o podjęciu działań, które mogłyby stanowić podstawę dla długofalowych zmian, jakie są obecnie konieczne do wprowadzenia w unijnej polityce w stosunku do jej najbliższego sąsiedztwa.

Co zrobiła Unia, jakie są fakty? Realne działania o charakterze politycznym ze strony UE obejmują głównie mało treściwe deklaracje w formie konkluzji przyjmowanych po kolejnych spotkaniach Rady Unii Europejskiej (RUE) - najczęściej w formule FAC, czyli Rady ds. Zagranicznych (Foreign Affairs Council). Ich retoryka przypomina delikatną połajankę Rosji za jej działania i werbalne wsparcie dla społeczeństwa Ukrainy, przy czym także zauważalna jest nuta tradycyjnej krucjaty unijnej dotyczącej demokracji, poszanowania praw człowieka, ograniczania przemocy itp. W późniejszym okresie, po zaostrzeniu kryzysu Unia potępiła aneksję Krymu, jednocześnie nie uznając tego aktu za prawomocny (20 marca 2014 r.), wprowadziła sankcje o charakterze typowo politycznym. W pierwszej kolejności - ograniczenie kontaktów dyplomatycznych, w drugiej - restrykcje personalne wobec osób odpowiedzialnych za destabilizację sytuacji na Krymie (zob. też: Rostowska, Toporowski, 2014). Dopiero w trzeciej fazie Unia zdecydowała się na wprowadzenie sankcji gospodarczych w stosunku do Rosji (UE przygotowała trzy rodzaje sankcji wobec Rosji. Kraje członkowskie podzielone, 2014). Sankcjom ekonomicznym sprzeciwiały się przede wszystkim: Włochy, Hiszpania, Cypr i Grecja. Gotowe na wprowadzenie sankcji gospodarczych były natomiast: Polska, Szwecja, Dania, Litwa, Łotwa, Estonia oraz Wielka Brytania,

Ukrainy w latach 2013-2014, Warszawa: Europejskie Centrum Analiz Geopolitycznych, (w przygotowaniu do druku). 
która początkowo była przeciwna. Kraje Beneluksu obawiają się skutków sankcji gospodarczych, ale ich nie wykluczają. Co ciekawe, nie ma także jedności w Grupie Wyszehradzkiej, gdyż Węgry i Słowacja wspierały stanowisko Berlina (UE przygotowała trzy rodzaje..., 2014), które początkowo było także przeciwne sankcjom (w Niemczech istnieje duży rozdźwięk pomiędzy „twardym” stanowiskiem kanclerz Angeli Merkel a znacznie bardziej miękkim prezentowanym przez lobby kręgów biznesu, ale także przez ministra spraw zagranicznych, Francka-Waltera Steinmeiera). Należy oczywiście pamiętać, że wszelkie sankcje, jak i inne działania skierowane „przeciwko” Rosji, nie pozostaną bez odpowiedzi, a najbardziej dotkliwie odczują to państwa słabsze, w tym Polska.

Konkluzje RUE w sprawie sytuacji na Ukrainie z 14 kwietnia, poza politycznymi oświadczeniami dotyczącymi potępienia zachowania Rosji wobec Ukrainy, nie zawierają żadnych „twardych” konkretów. Deklaracje dotyczą gotowości udzielenia wsparcia misji monitorującej pod egidą OECD, czy też niesienia pomocy Ukrainie w reformie cywilnego sektora bezpieczeństwa oraz przeprowadzania dalszych reform o charakterze politycznym ukierunkowanych na demokratyzację. Obiecuje się także wsparcie finansowe mające na celu przede wszystkim ustabilizowanie gospodarki, a także zabezpieczenie ciągłości dostaw energii. Jeden akapit, poświęcony działaniom Rosji, zawiera stwierdzenie, że dalsze próby destabilizacji Ukrainy przez Moskwę mogą doprowadzić do daleko idących konsekwencji o charakterze ekonomicznym w stosunkach pomiędzy UE a Federacją Rosyjską.

Unijne wsparcie o charakterze ekonomiczno-finansowym oparte jest przede wszystkim na decyzjach podjętych przez Komisję Europejską (KE) 5 marca 2014 r. Obejmują one kwotę przynajmniej 11 mld euro z budżetu unijnego i innych międzynarodowych instytucji finansowych, które miałyby być przekazane Ukrainie w kolejnych latach. Pakiet wsparcia zakłada pomoc makrofinansową - 1,6 mld. euro oraz na rzecz rozwoju - 1,4 mld euro (zob. też: Pakiet Wsparcia dla Ukrainy, 2014). Wszystko to wydaje się być kroplą w morzu potrzeb, uwzględniając dług publiczny Ukrainy oraz stan jej gospodarki i nikłe rezerwy, jakie posiada to państwo. Pakiet pomocowy obejmuje także wprowadzenie czasowego zniesienia ceł na ukraińskie towary eksportowe do UE (decyzja z 14 kwietnia 2014 r., obowiązująca od 23 kwietnia). Często się słyszy opinie, że Polska może stanowić wzór do naśladowania dla ukraińskiej gospodarki (S. Płóciennik i P. Toporowski, 2014). Warto zapytać, w jakim zakresie? Są to dwie kompletnie różne gospodarki (głównie ze względu na odmienne gałęzie przemysłu). Oczywiście pewne przyjęte przez Polskę rozwiązania mogą okazać 
się przydatne, jednak polska rzeczywistość jest zgoła odmienna od ukraińskiej, gdzie korupcja stanowi właściwie najistotniejszy czynnik patogenny, zaś zjawisko oligarchii wyznacza ramy wszelkiej działalności rynkowej.

KE zadecydowała także o utworzeniu Grupy Wsparcia dla Ukrainy, która ma na celu niesienie pomocy władzom ukraińskim we wprowadzaniu niezbędnych reform politycznych i gospodarczych dla osiągnięcia względnej stabilizacji kraju. Ponadto Komisja zobowiązała się pomóc Ukrainie w podjęciu działań na rzecz dywersyfikacji dostaw gazu, jak również objąć Ukrainę tzw. partnerstwem na rzecz mobilności (Mobility Partnership - zob. też European Union's support to Ukraine - update, 2014). Najważniejsze jednak wydaje się wsparcie w zwalczaniu korupcji, która to sprawa ma stać się przedmiotem kolejnych działań podejmowanych w ramach współpracy UE-Ukraina. Jednak, aby unijna pomoc była skuteczna, istnieje konieczność spełnienia przez Ukrainę szeregu wymagań o charakterze sine quibus non, które dotyczą m.in. konieczności istnienia proreformatorskiego rządu oraz zbudowania instytucji administracji publicznej. Wprowadzane reformy muszą natomiast zyskać akceptację społeczną, Unia zaś powinna służyć właściwym zapleczem eksperckim i zbudować adekwatną do potrzeb ofertę pomocową (zob. też: Kaca, 2014). Tylko w ten sposób możliwe jest osiągnięcie efektu synergii.

To, co pomoże Ukrainie uniezależnić się w pewnym stopniu od Rosji, to uzyskanie swego rodzaju gwarancji stabilności energetycznej. W tym celu UE może zaoferować Ukrainie zarówno pomoc finansową, jak i wsparcie technologiczne - modernizację systemu gazowniczego uwzględniającą dywersyfikację dostaw oraz rozbudowę infrastruktury. Unia ma wspomóc Ukrainę także podczas negocjacji z Gazpromem na temat restrukturyzacji długu. Rolą KE ma być również wszczęcie postępowania antymonopolowego, które nie dość, że ułatwi zawieranie kontraktów przez państwa członkowskie, to dodatkowo poprawi pozycję startową Ukrainy w kolejnych negocjacjach (zob. też: Dudzińska, Gawlikowska-Fyk, 2014).

Sankcje wprowadzone przez UE są w znacznej mierze nieskuteczne, ale także przynoszą szkodę słabszym państwom Unii, na których odbija się rykoszetem polityka odwetowa Rosji. UE nie udało się doprowadzić do potępienia Rosji na forum ONZ lub innych organizacji międzynarodowych ani do tymczasowego zawieszenia jej członkostwa w Radzie Europy (por. Kościński, Zasztowt, 2014) - udało się jedynie pozbawić Rosję prawa głosu. Takie działanie miałyby charakter wyłącznie symboliczny, ale jednak o wydźwięku międzynarodowym, stanowiącym jasny sygnał, iż nie ma zgody na tego typu zachowania ani miejsca w społeczności międzynarodowej dla państwa, które stosuje takie środki, jak 
Rosja wobec Ukrainy. Nie ma także żadnego międzynarodowego wsparcia, ani nawet większego zainteresowania ludnością krymską, która obecnie stała się mniejszością (mniejszościami) narodową, której prawa mogą być tam łamane „po cichu”. Wsparcie dla Ukrainy, jeśli chodzi o walkę z rosyjską propagandą i prowokacjami, jest żadne. Realne szkody Rosji przyniosło jedynie porozumienie pomiędzy Stanami Zjednoczonymi a Arabią Saudyjską w sprawie ropy naftowej.

Zasadniczo stanowisko całej Unii Europejskiej w jakiejkolwiek sprawie w ostatnim czasie uzależnione jest od opinii Niemiec, zatem w kwestii „Euromajdanu” nie jest inaczej. Berlin natomiast definiuje swoją politykę wobec Ukrainy przez pryzmat relacji z Rosją, te zaś zawsze były determinowane ideą współpracy i niechęci do konfrontacji. Dominowała raczej zasada włączania niż odseparowania Rosji od reszty Europy. Aneksja Krymu przez Rosję podkopała niemiecką ufność $\mathrm{w}$ rosyjską dobrą wolę do prowadzenia współpracy w zakresie bezpieczeństwa międzynarodowego, jednak nie przeformułowała zasadniczych kwestii związanych z podejściem prezentowanym przez Berlin (zob. też: Formuszewicz, 2014). Obecnie zasady polityczne wspierane są także przez argumenty ekonomiczne. Przez lata budowana przez Rosję sieć powiązań i uzależnień (od dostaw surowców) spowodowała głęboką niechęć znacznej części państw członkowskich do stosowania sankcji gospodarczych, które rykoszetem trafiają w gospodarki krajów unijnych. W rzeczywistości państwa członkowskie UE zdają sobie sprawę, że ich moc sprawcza względem prób wymuszenia zmian w zachowaniu Moskwy jest niezmiernie ograniczony, mogą przynieść więcej szkód ich własnym krajom niż korzyści. W UE, mimo powszechnych deklaracji, nikt nie myśli o „wyższym dobru wspólnym”. Stanowi ono tylko mit, złudne hasło łączące jedynie w teorii państwa członkowskie.

Zaniechania $\mathrm{z}$ lat poprzednich $\mathrm{w}$ kwestii budowania relacji z Rosją, akceptacja rodzącego się neoimperializmu w tym kraju i zgoda na jego rozwój (poprzez brak reakcji, gdy pojawiały się pierwsze jego symptomy o charakterze zarówno ekonomicznym, jak i politycznym oraz militarnym) doprowadziły do sytuacji, w której Rosja nie musi się specjalnie liczyć z opinią, ani nawet z działaniami (z racji ich braku) ze strony państw Zachodu. Błędnie prowadzona polityka wschodnia Unii Europejskiej wraz z niewłaściwym postrzeganiem wyzwań oraz płynących z nich szans i zagrożeń doprowadziła do sytuacji, w której jedyną „ofertą", jaką Unia przygotowała dla swoich wschodnich sąsiadów, było Partnerstwo Wschodnie (PW), realizowane bez większego zaangażowania ani pomysłu. Równolegle natomiast podpisywano bilateralne (zamiast wspólnotowe) umowy z Rosją (m.in. na dostawy gazu), przymykając oko na wiele alarmujących symp- 
tomów, jakie generowały rosyjskie władze. Moskwa nie życzyła sobie włączenia jej w projekt PW, domagała się od Unii specjalnego statusu wzajemnych relacji, które na szczeblu dyplomatycznym określano szumnie partnerstwem strategicznym. W rzeczywistości relacje te nie miały nic wspólnego z partnerstwem, tym bardziej strategicznym, natomiast idealnie zgrywały się z aktualnymi potrzebami Federacji Rosyjskiej, której działaniu faktycznie przyświecała od dawna wypracowana długofalowa strategia. Polega ona nie na rzeczywistej współpracy z UE jako organizacją, ale na budowaniu określonych relacji o charakterze bilateralnym z każdym z państw członkowskich z osobna. Niestety nikt w UE zdawał się nie dostrzegać zagrożeń płynących z obrania przez Rosję tego rodzaju strategii działania, co więcej, nikt się jej nie sprzeciwiał. Moskwa tymczasem budowała misterną sieć dwustronnych powiązań, aby móc z niej skorzystać (na zasadzie „sympatii” bądź szantażu) w odpowiedniej chwili. Tą chwilą okazała się rewolucja na Ukrainie.

Rosja zawsze sprzeciwiała się okcydentalizacji jej historycznych stref wpływów, stąd próby wciągnięcia Ukrainy w zachodnie struktury musiały zaowocować ostrą jej reakcją. Powstaje zatem pytanie, w jaki sposób powinna zachować się Unia Europejska, która, realnie oceniając, absolutnie nie jest zainteresowana rzeczywistą akcesją Ukrainy. Umowa stowarzyszeniowa miała stanowić jedynie gest, który był skierowany do prozachodnio nastawionej części społeczeństwa ukraińskiego, by zaspokoić jej aspiracje. Było także polityczną demonstracją „siły przyciągania” UE. Efekt jest niestety przynajmniej mizerny. Po raz kolejny ujawnił się w pełnej okazałości brak odpowiednich analiz oraz pewnego rodzaju zuchwałość Zachodu. Nikt nie zwracał uwagi na ewentualne konsekwencje, działania stowarzyszeniowe nie były przygotowane w sposób właściwy z punktu widzenia politycznego oraz propagandowego (brak prowadzenia długofalowych, wieloletnich działań mających na celu przygotowanie odpowiedniego „gruntu i atmosfery politycznej” do ewentualnych dalszych poczynań). Co więcej, nie zastanawiano się, co dalej, gdyż to, że w perspektywie najbliższych lat Ukraina nie zostanie przyjęta do Unii, jest chyba oczywiste dla wszystkich.

Obecnie Unia chce odgrywać rolę mediatora pomiędzy Ukrainą a Rosją, podczas gdy tak naprawdę rzeczywisty konflikt toczy się zupełnie gdzie indziej i żadnej ze stron nie zależy na Ukrainie, tylko na pokazaniu, kto jest silniejszy i ma więcej do powiedzenia, a przecież stawką są postradzieckie strefy wpływów - tereny, do których Rosja zawsze rościła sobie pretensje, jeśli nie terytorialne, to o charakterze wpływów i silnych zależności. Zdaje się, że Ukraina oczekiwała od UE podobnej oferty i zaangażowania jak w przypadku włączania w zachodnie 
struktury państw takich jak Polska, co odbywało się przy dużym wsparciu politycznym ze strony USA, które w ten sposób chciały powiększać swoją strefę wpływów. Obecnie, gdy Zachód nie „przemawia już jednym głosem” z USA, które zmniejszyły swe zaangażowanie w Europie, zmieniło się także podejście UE do Rosji (z rywalizacji oraz niechęci w stronę współpracy). Dla Ukrainy oznacza to przede wszystkim, że UE nie będzie się angażowała w spory z Rosją, aby bronić słabszą stronę. USA zaś, uważając Ukrainę za „obszar odpowiedzialności” UE, także nie chce wykonywać gwałtownych ruchów. Irracjonalność tej sytuacji polega na tym, że kraj, który chce „przygarnąć” Ukrainę, jest niechciany przez część społeczeństwa popierającą „Euromajdan” (zasadniczo zachodnia część Ukrainy), zaś organizacja (UE), do której społeczeństwo to się garnie, jest niechętna, aby przyjąć kraj z całym dobrodziejstwem inwentarza, czemu zresztą na dobrą sprawę trudno się dziwić. Ukraińska scena polityczna nie przedstawia sobą „godnego" partnera dla UE, zaś silnie nacjonalistyczne ugrupowania prawicowe również nie stanowią zachęty. Ewentualny podział Ukrainy przyczyni się z pewnością na początku do jeszcze większych problemów ekonomicznych jej zachodniej części, co wzbudzi kolejne niepokoje społeczne, podziały, chaos i być może upadek państwa. Unia Europejska nie jest zainteresowana takim scenariuszem, szczególnie w kontekście niedawno podpisanej umowy stowarzyszeniowej.

Brak jakichkolwiek konkretnych działań Unii spowodowany jest głęboką fragmentacją wewnątrz organizacji i daleko posuniętą niespójnością interesów. W kwestii Ukrainy Unia jest podzielona na przynajmniej cztery różne grupy (zob. też: Parkes, Sobják, 2014), które prezentują diametralnie różne podejścia, spośród których dominują te, które opowiadają się za chłodnym podejściem do spraw ukraińskich, niewielkim zaangażowaniem i przede wszystkim niedrażnieniem (delikatnie rzecz ujmując) Rosji. Większość państw jest też niechętna sankcjom na szeroką skalę w stosunku do Federacji Rosyjskiej.

Unia nie była i nadal nie jest w stanie zaprojektować takiego pakietu pomocowego dla Ukrainy, który pomógłby jej przejść głęboką transformację (Parkes, Sobják, 2014). Wynika to z braku wiary większości państw członkowskich w możliwości przeprowadzenia reform i demokratyzacji Ukrainy oraz sceptycznego podejścia w stosunku do jej ewentualnej unijnej przyszłości. Przeważająca liczba państw członkowskich posiada znaczące dla ich gospodarek kontakty handlowe z Rosją, a to oznacza, że gospodarczy pragmatyzm przezwycięży jakiekolwiek inne ewentualne sentymenty. Borykające się ze skutkami kryzysu państwa UE są zbyt słabe, aby podjąć gospodarczą wojnę z Rosją, nie mając w dodatku ku 
temu żadnej motywacji. Dla większości państw Ukraina jest odległym i mało interesującym politycznie oraz gospodarczo państwem, dla którego nie będą „nadstawiać karku” w imię „wyższych wartości”. Zarówno dla UE, jak i dla Stanów Zjednoczonych Ukraina jest jedynie niedużym pionkiem w wielkiej grze geopolitycznej i ekonomicznej, którego interesy nie będą brane w zasadzie pod uwagę podczas tej rozgrywki. Ukraińscy politycy opozycyjni nie chcą się pogodzić z taką sytuacją, ani nawet przyjąć jej do wiadomości i zdaje się, że ciągle czekają na cud, który się raczej nie ma prawa zdarzyć.

Większość państw jest skłonna przystać na rolę UE jako mediatora oraz okazać wsparcie społeczeństwu ukraińskiemu. UE chce pozostać jak najbardziej neutralna w tym konflikcie, podczas gdy Ukraina traktuje Unię jako stronę w sporze, organizację, która stoi wraz z nią po tej samej stronie barykady. Ta różnica w sposobie postrzegania przyczynia się także do rosnącego rozczarowania Ukraińców postawą Unii Europejskiej. O tym, że nikt poważnie nie myśli o przyjęciu Ukrainy do NATO czy EU dobitnie świadczy wypowiedź niemieckiego ministra spraw zagranicznych, Franka-Waltera Steinmeiera (2014), który stwierdził, że akcesja tego państwa do NATO byłaby jedynie „dolewaniem oliwy do ognia”, zaś jej członkostwo w UE to „sprawa dla pokoleń”.

Warto także przyjrzeć się reakcji NATO na kryzys ukraiński. Ożywił on z pewnością dyskusje dotyczące z jednej strony potrzeby istnienia NATO, ale także priorytetowych obszarów jego działania, jak również planowania strategicznego. Zaczęto się zastanawiać nad potencjałem obronnym, możliwością udzielenia realnego wsparcia określonym państwom w przypadku napaści zbrojnej (zob. też: Monaghan, 2014). Efektem tych dyskusji jest dostrzeżenie potrzeby podniesienia potencjału sił szybkiego reagowania NATO, czego wyrazem ma być decyzja o ulokowaniu NATO-wskiego centrum sił szybkiego reagowania w Polsce. Zaczęto także dostrzegać konieczność wprowadzenia zmian w zakresie komunikacji strategicznej (StratCom), która nie poradziła sobie z propagandą informacyjną Rosji. Podczas szczytu NATO w Walii we wrześniu 2014 r. państwa członkowskie dały jasno do zrozumienia, że nie będą się militarnie angażować w wojnę na Ukrainie. Poza zapewnieniami o tym, jak ważnym partnerem dla NATO jest Ukraina i że będzie rozwijana współpraca militarna (która miałaby polegać, jak można się domyślać, na wsparciu szkoleniowym oraz wspólnych ćwiczeniach), Ukraina nie otrzymała ani zapewnienia o otwartych drzwiach Sojuszu, ani deklaracji o wysyłaniu uzbrojenia czy sprzętu wojskowego. Podobnie jak UE, NATO ograniczyło się do okazania gestów solidarności i wsparcia, które mimo że są istotne na arenie międzynarodowej (miękka siła), to nie są w stanie 
powstrzymać działań Rosji. NATO przeznaczyło 15 mln euro na pomoc dla Ukrainy, zaś niektóre państwa członkowskie zaoferowały dodatkowo różnorakie formy pomocy, m.in. w sferze wojskowej.

\section{WNIOSKI}

Partykularne interesy poszczególnych państw członkowskich UE (przede wszystkim o charakterze gospodarczym) uniemożliwiają Unii osiągnięcie konsensusu odnośnie wspólnego działania, a nawet sformułowania wspólnego stanowiska. Solidarności w UE nie ma nawet wobec sytuacji, w której Rosja stosuje wybiórczo odwetowe narzędzia gospodarcze (restrykcje importowe) w stosunku do wybranych państw członkowskich (w tym Polski). Państwa te natomiast nie otrzymują praktycznie żadnego wsparcia czy ochrony w takiej sytuacji ze strony instytucji unijnych, a inne państwa członkowskie wręcz starają się zabezpieczyć własne interesy gospodarcze kosztem pozostałych. Jedyne spójne, jak do tej pory, działanie UE to nieuznanie aneksji Krymu i zdecydowany sprzeciw wobec tego typu działań, jakie podjęła Rosja wobec Ukrainy. Mimo że takie stanowisko ma duże znaczenie dyplomatyczne dla Ukrainy, jest to oczywiście działanie niewystarczające. Kijów natomiast traktuje je jako absolutnie podstawowe i takie, które powinno stanowić zaledwie punkt wyjścia dla kolejnych konkretnych kroków, nie zaś jako akt docelowy, czym z kolei wydaje się być dla UE, która najwyraźniej nie chce zająć żadnego bardziej kategorycznego stanowiska. Natomiast nieuznanie aneksji Krymu nie definiuje sposobu ułożenia przyszłych relacji np. między UE a Ukrainą z jednej a Rosją z drugiej strony.

Powstaje zatem pytanie, co więcej mogły lub czy nadal mogą zdziałać Unia Europejska oraz NATO w zderzeniu z „Euromajdanem”? Odpowiedź na to pytanie wcale nie jest prosta. Przecież nie chodzi o wywołanie trzeciej wojny światowej, ani nawet o stworzenie sytuacji przypominającej zimną wojnę. Nie służyłoby to niczyim interesom. Ukraina oczekuje jednoznacznego działania UE i NATO, które miałyby stanąć w obronie jej interesów, a co więcej - suwerenności. Pytanie tylko, dlaczego Unia lub NATO miałyby to zrobić? Nikt w Unii poważnie nie myślał o akcesji Ukrainy w perspektywie krótko, a nawet średnio-terminowej. Umowa stowarzyszeniowa jest jedynie gestem politycznym, natomiast obecnie Unia nie jest przygotowana na jakiekolwiek dalsze rozszerzenia, a już na pewno nie o kraj taki, jak Ukraina (z powodów politycznych, ale głównie ekonomicznych). Czasy, kiedy Stany Zjednoczone mogły wymusić na państwach Europy 
Zachodniej pewne zachowania dyktowane głównie amerykańskim interesem politycznym (w celu utrzymania priorytetowego dla USA balansu), dawno minęły, natomiast w interesie największych państw unijnych nie leży przyjmowanie Ukrainy do „elitarnego klubu”, który zresztą dawno przestał być elitarny. Mocarstwa europejskie zaczęły tworzyć mniejsze „kluby wzajemnej adoracji” zbudowane wokół konkretnych projektów wspierających ich partykularne interesy, głównie o charakterze gospodarczym, bądź szerzej - ekonomicznym, w którym znaczącym elementem układanki jest Rosja.

Jedynym w miarę spójnym podejściem prezentowanym przez państwa UE oraz NATO jest demonstracja wsparcia i solidarności ze społeczeństwem ukraińskim. Pozostałe działania dobitnie wskazują, jak bardzo rozbieżne interesy polityczne prezentują państwa UE i NATO, a kierunki ich działań są odmienne. Spowodowało to ogromne ograniczenie opcji działania, jakie mogły podjąć te organizacje tak, aby była na nie zgoda wszystkich państw. Działania te były i nadal są także w znacznym stopniu dyktowane przez dyplomację niemiecką (UE) oraz USA (NATO), co także w dużej mierze je ukierunkowuje i ogranicza. Obecnie wydaje się, że UE nie posiada żadnej długoterminowej strategii wobec „nowej Ukrainy” ani w kontekście działań o charakterze pomocowym, ani przyszłego podejścia o charakterze politycznym. Co więcej, nie ma także pomysłu na działania o charakterze doraźnym. Na Ukrainie zaś rośnie rozczarowanie postawą Unii Europejskiej.

Wydaje się, że UE i NATO zależy najbardziej na zachowaniu status quo, aby nie trzeba było podejmować żadnych ważnych decyzji, które wymuszałyby podejmowanie konkretnych działań prowadzących w efekcie do daleko idących zmian w ładzie europejskim. Pytanie, jakie się rodzi, jest następujące: jak wysoki będzie koszt tego pozornego „niezmienionego stanu rzeczy”, bo już i tak przestrzeń polityczna i bezpieczeństwa zostały poważnie zmienione poprzez dokonania rosyjskiego przywódcy na Kaukazie, w Czeczenii, a teraz na Ukrainie.

\section{BIBLIOGRAFIA:}

Dudzińska, K., Gawlikowska-Fyk, A. (2014). Rynek gazu na Ukrainie: główne wyzwania i możliwe działania UE. Biuletyn PISM, nr 41 (1153).

European Parliament ratifies EU-Ukraine Association Agreement (2014). Pobrane z: http://www.europarl.europa.eu/news/en/news-room/content/20140915IPR62504/ html/European-Parliament-ratifies-EU-Ukraine-Association-Agreement.

European Union's support to Ukraine - update (9 April 2014), Brussels: European Commission Memo. 
EU-Ukraine relations (17 April 2014), Brussels: Fact Sheet No. 140417/03.

Fettweis, C.J. (2010). Dangerous Times? The International Politics of Great Power Peace. Washington: Georgetown University Press.

Formuszewicz, R. (2014). Germany's Policy towards Russia: New Wine in an Old Wineskin. Policy Paper, nr 7 (90). W: Biuletyn PISM (2014).

Kaca, E. (2014). Unijny pakiet pomocy dla Ukrainy: jak zwiększyć jego skuteczność? Biuletyn PISM, nr 25 (1137).

Kościński, P., Zasztowt K. (2014). Secesja Krymu - konsekwencje dla Ukrainy, Rosji i Europy. Biuletyn PISM, nr 31 (1143).

Monaghan, A. (2014). Kryzys ukraiński a stosunki NATO-Rosja. Przeglad NATO.

Pakiet Wsparcia dla Ukrainy (5 marca 2014), Bruksela: Komisja Europejska.

Parkes, R., Sobják, A. (2014). Understanding EU Action during "Euromaidan": Lessons for the Next Phase. Strategic File, nr 5 (41). W: Biuletyn PISM (2014).

Płóciennik, S., Toporowski, P. (2014). Ukraina w opałach: pomoc finansowa, reformy, oczekiwania. Biuletyn PISM, nr 23 (1135).

Rostowska, M., Toporowski, P. (2014). „Kłopoty za wschodnią granicą - następstwa dla europejskiego biznesu". Biuletyn PISM, nr 37 (1149).

Sheehan, M. (2009). Ewolucja nowoczesnych wojen. W: Baylis, J., Wirtz, J., Gray, C.S., Cohen E. (red.). Strategia we współczesnym świecie. Wprowadzenie do studiów strategicznych. Kraków: Wydawnictwo Uniwersytetu Jagiellońskiego.

Szef MSZ Niemiec nie widzi Ukrainy w NATO. A w UE? „Zadanie dla pokoleń” (2014). Pobrano z: http://www.tvn24.pl/wiadomosci-ze-swiata,2/szef-msz-niemiec-niewidzi-ukrainy-w-nato-a-w-ue-zadanie-dla-pokolen,491639.html.

Toffler, A., Toffler, H. (2006). Wojna i antywojna. Jak przetrwać na progu XXI wieku? Poznań: Wydawnictwo Kurpisz.

UE przygotowała trzy rodzaje sankcji wobec Rosji. Kraje członkowskie podzielone (2014). Pobrane z: http://www.rmf24.pl/raport-ukraina/fakty/news-ue-przygotowala-trzyrodzaje-sankcji-wobec-rosji-kraje-czlon,nId,1410603. 